\title{
'Cheap option' UK science courses under fire
}

London. Britain's Royal Society has added its voice to that of science teaching bodies in criticizing the government's curriculum advisers for not encouraging some 14-16-yearolds to study more science than the minimum stipulated in the national curriculum.

The criticisms form part of the society's comments on proposals drawn up by the government-funded School Curriculum and Assessment Authority (SCAA) for a broadranging reform of the curriculum.

Science is one of seven subjects that all pupils must study up to age 16 under the national curriculum. Single-award science, which is equivalent to a single pass at GCSE (examinations taken at the age of 16), is intended to cover the three principal sciences in the statutory minimum of 10 per cent of curriculum time, and is recommended by SCAA for a 'minority' of pupils with a good reason for focusing on other subjects.

But the Royal Society, the Association for Science Education and the National Union of Teachers all argue that this is a second-best option to the so-called 'doubleaward course', taught in 20 per cent of the curriculum, and that it seriously limits opportunities for further study of science.

The scientific bodies argue that the demands on the course mean that the coverage of topics that have not been dropped completely is "superficial".

The result, they say, is to leave such pupils ill-equipped to deal with issues "in a society where science and technology are part of everyday life". And it closes off further study of science after the age of 16 , conflicting with the government's goal of a balanced curriculum.

The Association for Science Education (ASE) had already written to Sir Ron Dearing, chairman of SCAA, earlier this year asking for clarification of the government's intention after an interim report led to confusion over how much science was needed for the average child.

ASE officials claim that some head teachers had interpreted SCAA's recommendations as meaning that a majority of pupils should take the single-award option, and had seen this as a way of easing pressure on tight budgets and timetables.

Dearing reaffirmed in the proposals recently published for comment that SCAA expects "the large majority" of pupils to study double-award science. But the ASE says it remains "very concerned" that he did not recommend that all pupils between the ages of 14 to 16 should spend 20 per cent of curriculum time on science.

SCAA's review of the national curriculum, which was introduced in 1988, was commissioned in 1993 after the government received widespread criticism from teachers and academics. Its conclusions will be presented to Gillian Shephard, the newly appointed Secretary of State for Education, in the autumn, once the responses to a consultation document sent out in May have been analysed.

Both the National Union of Teachers and the ASE also say they are concerned that

\section{IMAGE \\ UNAVAILABLE \\ FOR COPYRIGHT REASONS}

\section{Concern is growing that some school science courses are too superficial.}

general availability of single-award science will reverse the recent increase in the number of girls taking science after the age of 14, which they argue has been achieved through the national curriculum and balanced science courses.

Their concern is based on statistics showing that girls are in a slight majority of the 12 per cent of pupils taking single-science courses, and in a minority of the 82 per cent taking the double-science option. (The remaining 6 per cent of pupils still take the traditional "single subject" courses at GCSE.)

Maggie Verrall

\section{Zeneca cuts seeds but enters genome technologies}

London. The decision two years ago by the UK company Imperial Chemical Industries (ICI), in the wake of a failed hostile takeover bid, to split off its science-driven activities into a new company, Zeneca Group plc, seems to be paying off (see Nature $\mathbf{3 6 2}$, $780 ; 1992$ ).

Last week, Zeneca announced pre-tax profits for the first six months of this year, excluding exceptional items, of 31 per cent, considerably higher than the market had been expecting.

The company's shares were expect to receive a further boost this week with the announcement that Zeneca's subsidiary Cellmark Diagnostics is launching a longawaited screening kit for cystic fibrosis.

The news is not all good. Zeneca has also announced that, as a result of the continuing 'economic disorder' in the countries of eastern Europe it is withdrawing from its hybrid seeds business in the region, a move that will involve writing off $£ 100$ million (US\$154 million) - and could lead to the loss of up to 500 jobs in Britain and elsewhere.

It has also encountered difficulties in increasing sales in the United States of the anti-breast cancer drug tamoxifen, sold under the brand name Nolvadex, following controversy over the conduct of trials of the preventive use of the drug in the United States (see Nature 368, 679; 1994).

Nevertheless analysts appear to be endorsing Zeneca's claims to have a healthy "product pipeline", with clinical trials well advanced on, for example, new drugs for the treatment of breast and colo-rectal cancer.

One of the factors behind the decision to split ICI (the bulk chemicals businesses are now concentrated in ICI plc) was to enable Zeneca to focus more sharply on developing the applications of advanced science-based techniques in pharmaceuticals and agrochemicals.

Peter Doyle, formerly research director of ICI and now an executive director of Zeneca, cites the company's recent announcement of a new variety of banana, genetically engineered to reduce its susceptibility to rot, as an indicator of progress in this direction.

Zeneca has recently come under some criticism for its apparent tardiness - at least in comparison to rivals such as Glaxo and Roche - in entering the field of human 'genomics', in particular the gene-based diagnosis and treatment of diseases.

Tom McKillop, chief executive officer of pharmaceuticals, disputes these criticisms: Zeneca's recent decision to establish a human genetics group as well as the launch of Cellmark's cystic fibrosis kit underline its commitment to this field, he says.

The company is also believed to be preparing to announce a strategic alliance with an outside research group in human genomics. Such an alliance was announced two weeks ago between Glaxo and the San Diego 'gene-hunting' company Sequana.

For the time being, however, Zeneca's most public excursion into the domain of genome technologies has been the selection of Cellmark's US subsidiary by the Los Angeles police department to conduct the DNA profiling tests on evidence in the trial of O. J. Simpson, the former football star charged with murdering his former wife and her male friend. 